Meta

Journal des traducteurs

Translators' Journal

\title{
Three Masters of Russian Translation
}

\section{Victor Rozencveig}

Volume 38, numéro 4, décembre 1993

Le Je du traducteur

The $I$ of the Translator

URI : https://id.erudit.org/iderudit/004007ar

DOI : https://doi.org/10.7202/004007ar

Aller au sommaire du numéro

Éditeur(s)

Les Presses de l'Université de Montréal

ISSN

0026-0452 (imprimé)

Découvrir la revue

Citer cet article

Rozencveig, V. (1993). Three Masters of Russian Translation. Meta, 38(4), 643-657. https://doi.org/10.7202/004007ar
Résumé de l'article

Victor Rozencveig présente l'expérience de trois grands maîtres de la traduction russe : le poète Boris Pasternak, le poète et traducteur Mikhail Lozonskij et le philologue et traducteur Mikhail Gasparov. Il donne également les notes de traduction de Boris Pasternak sur Shakespeare, l'échange de correspondance entre Boris Pasternak et Mikhail Leonidovic et les expériences personnelles de traduction de Mikhail Gasparov. 


\title{
THREE MASTERS OF RUSSIAN TRANSLATION
}

VICTOR ROZENCVEIG

Linguistic University of Moscow, Moscow, Russia

\begin{abstract}
Résumé
Victor Rozencveig présente l'expérience de trois grands maîtres de la traduction russe: le poète Boris Pasternak, le poète et traducteur Mikhail Lozonskij et le philologue et traducteur Mikhail Gasparov. Il donne également les notes de traduction de Boris Pasternak sur Shakespeare, l'échange de correspondance entre Boris Pasternak et Mikhail Leonidovič et les expériences personnelles de traduction de Mikhail Gasparov.
\end{abstract}

Russian translators are represented in the present issue by the poet Boris Pasternak, poet and translator Mikhail Lozinskij and philologist and translator Mikhail Gasparov.

The foreign reader knows Boris Pasternak as the author of Doctor Zhivago. Less known is his poetry and altogether unknown, naturally, is Pasternak as translator. However, even among Russian poets who traditionally combined their own creative work with constant endeavours to internalise the achievement of world culture, Boris Pasternak stands out due to the scope and originality of his work as translator. Suffice to say that he translated Shakespeare's dramas - Hamlet, Romeo and Juliet, Anthony and Cleopatra, Othello, King Lear, Henry IV , Macbeth - Goethe's Faust (both parts), Byron's Stanzas, Shelley's and Keats' poems, Goethe's lyrical verse, Rilke, Verlaine, Verhaeren, modern Polish, Czech and Hungarian poets. The combination of small and great, national and universal can be accounted for by Pasternak's Poetics. In his article General Purpose of Translation which is presented here, Pasternak wrote: "Drawing the 1905 naval revolt in a poem or copying into Russian poetry a page of English poetry... were tasks of the same order and equally testing to the eye and the ear." Also, about his translation of Faust: "A source of happiness and delight in its novel for me was the present state of Russian lyrical speech which allowed Goethe's meaning to rattle and to roll through in Russian with some primary originality..."

However, it was another thing that pushed Pasternak towards translation: the impossibility to express in his own creative work the discord, of which he became aware in the 30 's, between himself and the word of illusions in which he had lived. Here is what Pasternak said about it later:

It was in 1936 when those trials (Stalin's 'trials' against the opposition - V.R.) began, while I hoped to see the end of atrocities in 1935, that everything was crushed within me and unity with time turned into confrontation which I did not conceal. I took refuge in translation...

Refuge? "Translations make no sense", he wrote in those years,

unless their ties with the originals are closer than it is assumed. Correspondance with the text of the original is too weak a tie to make a translation worthwile... For the translation to reach its purpose it should be tied with the original by a more essential dependence. The relations between the original and translation should be those of a plant and its layer. Translation... should be the fruit of the original and its historical consequence. 
This understanding of translation alongside with the scope of B. Pasternak's translation work brings him into typological relationship with the great cultural figures of the past who emerged during the periods of collapse of old social, ideological and aesthetic systems and of revaluation of the accepted values. About his translation of Hamlet Pasternak wrote:

The translation should be judged as an original Russian dramatic work, for besides precision, equilinearity with the original, etc., it has more of that intentional freedom, without which one cannot approach great things.

About his Faust Pasternak said:

...It was written with my heart's blood, alongside with this work and overlapping with it there was prison and other things, and all those horrors, and guilt and faithfulness.

Contraposing the vital power of translation to verbal precision, Pasternak does not see himself outside the Russian tradition of poetic translation or standing apart from the poets and translators who worked side by side with him. Illustrative from this point of view is his letter to another master of Russian translation, Mikhail Lozinskij. Within more than three decades of his work Lozinskij translated plays by Lope de Vega and Tirso de Molina, Corneille and Moliere, memoirs by Bienvenutto Cellini, Colas Brugnon by Romain Rolland and much, much besides. Lozinskij's life work was the Russian translation of Dante's Divine Comedy. This work alone enabled the wonderful Russian poetess Anna Akhmatova to say that "in the hard and noble art of translation Lozinskij was for the 20th century what Zhukovsky had been for the 19th", i.e. to put Lozinskij next to the genius of Russian poetic translation. Unlike Pasternak, Lozinskij is primarily a translator. His understanding of the art of poetic translation he define in the following way: "Translator of poetry should allow as little deviation as possible, steer against the wind, reduce manoeuvring to a minimum." It is obvious that this method of translation is the opposite of Pasternak's approach. However, in their understanding of the necessity for multiple versions of the same original Pasternak and Lozinskij are at one. As the reader may see from Lozinskij's reply to Pasternak's letter, they also see eye to eye on the translator's professional ethics.

The third master of Russian translation represented here is Mikhail Gasparov, a philologist and translator. Author of fundamental works on versification - Modern Russian Verse (1974), Outline of the history of Russian Verse (1984), and Outline of the History of European Verse (1989) - Mikhail Gasparov makes a contribution to Russian literature with his translations of antiquity - Aesop and other authors of fables, Pindar, Ovidius, Aristotle's Poetics and Horace's Ars Poetica, medieval Latin poetry - as well as modern European poetry. Both as a specialist in classical philology and as a poet and translator, Mikhail Gasparov is interested in the ways of transferring from one poetic culture to another, structurally distant, and studies the variations in style and precision. The Experiments for Myself which he speaks about here, go far beyond the limits of a private study room: they deal with the assessment of different degrees of precision in translation understood not as a statistical, but a stylistic measurement. He writes: "Style means, roughly speaking, finding the right degree of archaisation and vulgarisation of the text." The degree changes, naturally, depending on how much the source culture and language has in common with the target culture and language and is manifest in translation not in chronological but in typological closeness. For instance, the older Latin writers who imitated classical authors and classical authors themselves Gasparov translated using a more modern variety of Russian whereas to translate the more recent medieval Latin writers he chose archaic Russian, thus creating a true stylistic perspective. In a similar way Gasparov built the historical and stylistic perspective when he translated historians of different generations. The degree of precision may 
naturally vary depending on the genre to which the text belongs and on the purpose of translation: for a scientific paper Gasparov translated Horace's Ars Poetica in prose, preferring a poetic translation for a collection of Horace's verse.

Gasparov's experiments in poetic translation as well as his adapted and abridged versions are instructive both for practising translators and for specialists in the theory of translation. To the readers familiar with the works of Eugen Nida, the notion of stylistic precision developed by Gasparov will bring to mind the notion of "dynamic equivalence".

His Experiments for Myself M. Gasparov finishes off with the words: "However, there is a long way to go till the end - maybe, nothing will come of it." To a certain degree this is true about any story of experience told by a master. Indeed, can you share your experience, pass it on to someone? And can one take this experience? What remains is to hope that the mediations of masters of Russian translation about their quest and discoveries will help translators in their search for adequate solutions.

\section{BORIS PASTERNAK, NOTES ON TRANSLATION}

\section{ON SHAKESPEARE}

The declaration of war tore me away from the first pages of Romeo and Juliet. I put the translation aside because I had to see off my son who was going to do defensive work, that and a lot of other worries made me forget about Shakespeare. During the weeks that followed everything willy-nilly was dominated by the war. In the nights when there was bombing I was on duty on the roof of a twelve storey block of flats - witnessed two demolition bombs hit the bulding during one of my vigils, - made a dugout near the place where I had a country house, and took a course of battle training which unexpectedly revealed in me a borned marksman. My family had been evacuated deep into the country. I longed to see them all the time.

At the end of October I went to join my wife and children, and winter in a provincial town, far away from the railway line, on the bank of a frozen river which was normally the only means of communication, cut me off from the world and for three months set me back to work on the abandoned "Romeo".

Shakespeare will always remain the favourite of any historically mature and experienced generation. Numerous ordeals teach us to value the voice of facts, the real knowledge, and the pithy and serious art of realism.

Shakespeare remains the ideal and the summit of this tendency. Nowhere else does the understanding of man reach such correctness, none has related it so wilfully. At first sight these two qualities seem incompatible. Yet, there is a direct connection between them. By the lawlessness of his style which so irritated Voltaire and Tolstoy, Shakespeare shows what a volcanic structure our much trumpeted artistic objectivity really has. The first thing about Shakespeare is that he is a miracle of objectivity. Look at his famous characters, they are a whole gallery of types, ages and temperaments with their idiosyncrasies and individual languages. And Shakespeare is not worried by the fact that their words interwine with the outpourings of his own genius. His aesthetic is built upon the alternation of self-oblivion and attentiveness, of the lofty and the ridiculous, of prose and verse.

$\mathrm{He}$ is the child of nature in all respects: be it his unbridled form, his composition and manner of modelling or his psychology and the moral content of his dramas. Shakespeare's imagery is exceptionally explosive. His similes are the treshold that the subjective in poetry has never crossed. He left a deeper personal imprint on his works than anyone before or since.

His presence can be felt not in their originality alone. When he writes about good and evil or about truth and falsehood we perceive a view of the world which would be 
inconceivable in an atmosphere of servility and obsequiousness. We hear the voice of a genius, a king among kings, the judge of the gods, the voice of western democraties to come whose foundation is the pride and dignity of the toiler and the fighter.

I have always wanted to translate Shakespeare's dramatic chronicles. Our times make us view them with a new interest. The two Richards are virtual holy writ for the historiographer. But in literary work, like in any other, one has to be guided by practical considerations.

A year or two ago I translated Hamlet, last winter, Romeo and Juliet. What can I say about the principles of my translation? The greatness of the original saves me from excessive explanations. In respect to Shakespeare only complete naturalness is possible coupled with complete freedom of mind. For the first I trained myself as well as I could in the course of my own writing, for the second I am prepared by my convictions.

It is winter again. I am going once more to stay with my family in that obscure town on the Kama and will if providence wishes it, get down to translating Anthony and Cleopatra for a production that is to be staged at the Moscow Art Theatre.

\section{GENERAL PURPOSE OF TRANSLATION}

The translations of several plays by Shakespeare... form a natural continuation of our work. In the books under our name which came out before the revolution and during its initial stage we tried to the best of our ability to express in poetry and prose our individual view of nature and life. Later $A$ Safe-Conduct came out which was an essay on our views of the inner essence of art. The translations from Shakespeare presented here illustrate a further development of the same views.

In them, as well as in our original writings, we tried to give the fullest possible idea of the subject in question, in this case, of the original to be translated. We saw our purpose as grasping its essence in as lively and natural a manner as was possible and in rendering it with the utmost similarity to the original.

It basically makes no difference to the artist whether he draws a ten miles deep perspective in the open air or copies a ten miles deep perspective from Tintoretto or Veronese in a museum. Here, except for some particulars of lighting, the laws are quite the same. Drawing the 1905 naval revolt in a poem or copying into Russian poetry a page of English poetry, the greatest in the world, were tasks of the same order and equally testing to the eye and the ear, equally gripping and tormenting.

In the course of this work we were wary lest the restraint caused by it should narrow down our scope, which is what usually happens to people working in a narrow field. Convinced of the fact, that a true translation should stand firmly on its own two feet, that we should not blame our weaknesses on the alleged lameness of the original, we set ourselves all the requirements, necessary for any literary work standing on its own.

\section{HAMLET, PRINCE OF DANEMARK}

It was several times suggested to me that I should translate Hamlet. The inducements came from the theatres. Since many good translations already existed, I did not see the point of adding another one, that would be no more than a slight modification of the others. The idea was, however, to create a special, free version that could be easily perceived as a stage variation and not as a book. Finally, fascinated by the task, I changed my mind.

To increase my chances of success I translated with blinkers on, as it were, face to face with the text, a dictionary and a small editor's commentary. Several months later, when the first rough draft was finished I took the translations by Kroneberg and K.R., which I did not remember, together with the new translations which I had not read, those by Sokolovskij, Radlova and Lozinskij, and started comparing. What came to light? It 
appears that the laws of the language coupled with the identity of the subject matter are much stronger than one would suppose. The manuscript was full of similarities and coincidences with the other translations and, in view of its insignificant originality, was not fit to be placed beside them.

On the other hand, it was the best way to test in practice the advantages of the other versions. Firstly, they were not the result of a caprice. My own failure taught me how difficult it is to bypass them while remaining within the bounds of accuracy. The critics do not show much gratitude to them and they themselves are not always fair to each other.

Breadth of learning and an elevated style distinguish Kroneberg's translation. K.R. is more reserved and closer to the original; he achieves a greater clarity by subjecting the rhythmical stress to the semantic. Radlova's artistic achievement is the vividness of spoken language. She has an absolute ear for theatrical credibility which always goes with a gift for drama, without which it would be impossible to translate the prosaic passages of the dialogue the way she did it. From the point of view of precision combined with good language and strict form Lozinskij's translation is ideal. It is both a stage version and a book for reading, but most of all, it is the only source for a scholar who does not know English, because it gives the best impression of the way the original looks and of its vocabulary, which it obediently replicates.

In the face of such creations, which will always be at the disposal of those who need them, I could with a light heart abandon the failed project and busy myself with the more remote task, set for me by the theatres at the very start. From the translation of words and metaphors I turned to the translation of thoughts and scenes.

The translation should be judged as an original Russian dramatic work, for besides precision, equilinearity with the original, etc., it has more of that intentional freedom, without which one cannot approach great things.

\section{LETTRE TO LOZINSKIJ}

Dear Mikhail Leonidovič,

1st March 1940

I feel very guilty indeed, though I never would or could do anything to offend you. But now there is yet another reason for me to feel guilty: the lettre which I have been writing in my head for three months will already come so late that even the fact of my writing to you after all this time will make you laugh, so maybe it would be wiser now not to write at all.

I'll try and tell you everything all at once, as everyone of my words should be a joy to you. When you did me the honour of sending me the wonderful present of your translation of Dante's Inferno, I was already predisposed towards you. I knew that you had done one of the new translations of Hamlet and when I wrote the first draft of my own translation I took care not to look at it, or any of the other existing translations. In that state of mind it was rather difficult (or so I imagined then) to write to you.

Then there was a different period. Editing and rewriting my translation, I compared it with all the others, so as to take into consideration all that had been done before me.

You may know that I did not start this translation on my own initiative. The inducement came from the theatres, from Mejerhold among others. I had always referred everyone to the existing translations of which I knew the old one by Kroneberg, or perhaps the one by K.R., i.e. something in between, which had become rather vague in my memory. I referred everyone to the old and the new translations without looking at them, being deeply and gratuitously sure that they must be good and that the theatres were being too choosy and obviously did not know what they really wanted. One so rarely gets one's 
hands on new books these days that I did not know which one of you four - yourself, Radlova, Kumzin or Zenkevič - had produced a new Hamlet, nor did I know that there were not one but two new versions. But that was only at the beginning. That is what I thought but I did not realise how right I was. When I had looked through five or six versions, my heart sank: the philological closeness to the original, the literary elegance and the theatrical effectiveness surpassed all my premonitions. And the coincidences, the coincidences! Incidentally, I soon gave a rank to each version, although, of course, they retain their individual merits: of the old ones Kroneberg's seemed to me the best, yours was the best of all.

There was a time when, under the weight of the coincidences between our translations, I was going to admit that my attempt had failed, lay down my arms and send you congratulations upon my defeat. Firstly, engrossed in your translation, I felt painfully ashamed that I had not read it before, i.e. that with a translation like yours already in existence I could agree, albeit under pressure, to write another one. I was ashamed that from the point of view of conscience and taste I had, through ignorance, acted against my sense of duty.

Also, I was struck by the abundance and the nature of the coincidences that I found in my translation comparing it with yours. They were all sentences that fitted quite naturally into the iambic pentameter, those very sentences whose naturalness, while pleasing me (during the work on the first draft), always caused me some premonition that I was probably not the first to think of them.

These lines in my translation coincided with yours word for word to the last coma, even as actual lines on the page, i.e. as some indivisible linotypic units. For example,

No kak vovek ne drognet dobrodetel'

$c f$. the original: But virtue, as it never will be mov'd

or

On vz'al men'a za kist' i krepko szhal

$c f .:$ He took me by the wrist, and held me hard, etc.

I left only some of them (and there were a lot, upon which I should congratulate you) and only those which are the same in all, or at least in some of, the other translations. It was you, who made me edit what I had done anew. But no! Write the whole translation afresh.

What came of all this work? As a result of all the jolts and shifts in the translation I naturally reached what the theater had been inducing me to do and what could have been predicted from the very start. All the other translations retain the rank they had before, not a single one was surpassed or made redundant by mine. Alongside the translations proper there has appeared a freer, more simple and lighter stage variation af the same text. This is what happened after the attempt to render another heavy-but-precise version had failed, as it had been to an extent an imitation of its predecessors.

You will surely understand what a joy this work has been to me as it is not tainted by any competion with my colleagues. On the contrary, this work in itself has really opened my eyes to the true worth of their achievements. This joy was partly marred by Kornej Ivanovič's attacks on Radlova. They are certainly unjustified. I like her Hamlet, the liveliness and naturalness of its speech, especially in the prosaic passages, which are in some cases masterly. I do not know Anna Dmitrievna's address otherwise I would write her a letter of support. Obviously, K.I. is now going to have a go at you and me. He has read her Hamlet just recently (he knew her other translations) and to my great delight he 
praises it. This means that we shall have to suffer in her stead, such is their very peculiar system of thinking: in this respect he and $\mathrm{R}$. are very similar and would be good partners.

Your Dante is an absolute miracle. You have done all that the partly inhuman and partly boring and grumpy original allowed you to do. All the descriptive oases are rendered with gripping fascination and I am painfully sorry for you when the crazy old man drags you off into the desert again. But one should not write about such things as an afterthought.

I have spoken of nothing but you all year, you must have heard about this from others. How is your health? Write and tell me that you have forgiven me.

Yours, B.P.

MIKHAIL LOZINSKIJ

LETTER TO PASTERNAK

Dear Boris Leonidovič,

17th March 1940

I am sorry that I took so long to answer your kind letter, but I have been feeling particularly bad of late and it is not so easy to catch a lucidum intervallum for discussion.

I was sorry to learn that I unwittingly caused you any unpleasant thoughts. Do tou really think that $I$ could feel the slightest bit wounded or that I could frown when I learnt that you translated Hamlet, as I myself did some time ago?

I learnt about it recently from A.D. Radlova when Kornej Ivanovič's famous article appeared and I must assure you that my only reactions were a great interest in your work and the joyful anticipation of reading another Russian version of Hamlet, created by an outstanding master. Only one thing could spoil this serene feeling: not receiving a copy of the translation from you when it comes out. This is why, without standing on ceremony, I beg you to add me to your list of humble petitioners for a copy.

I cannot but comment on a very important point. You write that in your first edition there were quite a few coincidences with my translation. This obviously means that we applied the same method - "steering against the wind", as close as possible to Shakespeare, to his style. In any case, these coinciding lines are part and parcel of your translation, the vital veins of its integral circulatory system. Then how can you severe them and put in rubber tubes instead? I think that you should by no means exclude something that you came to naturally only because the same thing is part of an earlier translation. My translation of Dante's Inferno is very unlike Min's in style, but some of the verses coincide to the letter: they are the most natural solutions. When I discovered these coincidences post factum I did not change my version.

I take it that in your second draft you restructured the whole translation, bringing it into a new focus which was not so sharp but more pleasant to the eye. This is very interesting and it must be beautiful. But what a loss the first, precise version is! If we used the same method - the same target, the same range, the same weapon - how instructive it would have been for me to compare the results of the shooting!

I do not know which edition of my translation you had then. I am saying this because in the first edition (Skol'naja Biblioteka Klassikov, GIHL, Moscow, 1933) my text was badly distorted in some places by the editorial staff - without my knowledge and in this distorted version it was reprinted in Skol'naja Serija Klassikov (GIHL, Moscow, 1935). I take responsibility for the other editions. There are a number of differences: from edition to edition I changed certain things (the version for children Detizdat, Leningrad, 1938 - stands apart many things are simplified in it). The definitive 
text is now being published as a separate book in Moscow (GIHL); unfortunately, I have not read the proofs yet.

When is your translation coming out? When is the premiere at MHAT?

Did you go to the conference on Shakespeare? It seems it was no sight for those of a nervous disposition. I did not manage to get to Moscow at all this winter.

You have got me engrossed in Dante again. If it were not for your praise, I would have thought twice before doing it. Now I am already half the way through Purgatorio, and have translated 17 songs. How hard it is, oh, how hard!

If I am so lucky as to get to Moscow this spring, I would like to see you very much. Or maybe you will be coming to Leningrad? It is so light in the evenings now, so beautiful!

Yours, M. Lozinskij

\section{NOTES}

\section{B.L. Pasternak}

- "Notes on Translation", first published in the collection The Art of Translation (1966), Moscow (1968).

General purpose of translation:

- A safe-Conduct, an outline of Pasternak's poetics, Leningrad (1931).

- "Drawing the 1905 naval revolt in a poem...", Pasternak here refers to his poem (1905), Moscow (1927).

- Hamlet, Pasternak undertook the translation of Hamlet upon the request of V.E. Mejerhold (1874-1940).

In the very heat of that work, writes E. Pasternak, the poet's son and biographer, there came news of Mejerhold's arrest on June 20,1939 and the following (in 25 days) murder of his wife, Z.N. Raikh.

In summer, two days before Mejerhold's arrest, Marina Tsvetaeva came to Moscow. About two years before that her daughter and husband had returned to Moscow from Paris where they had lived in emigration. On August 28 of that same 1939 her daughter was arrested, then - on October 10 - her husband.

In the letters of that time - writes E. Pasternak - showing and bursting through is the feeling that very few years and very little strength has been left, the unbearable guilt and woe in the face of what is going on around. Work on the translation of Hamlet was rescue from this torture. Pasternak subjected all his life schedule to it without sparing himself, set himself daily assignments that he could barely fulfill, worked for ten or twelve hours a day...

Having completed the translation, Pasternak wrote to his father:

The translation is simple to the extreme, smooth, understandable from first hearing and natural. In a period of false rhetorical pomp, the need for straight independant word is great, and I willy-nilly served this need.

The translation was published for the first time in 1940.

- "I took the translation by Kroneberg and K.R....": A.I. Kroneberg, Konstantin Romanov and A.L. Sokolovskij are the authors of Russian translations of Shakespeare of mid-19th to early 20th-century. The translations by A.D. Radlova and M.L. Lozinskij were published respectively in 1937 and 1933.

- Letter to Lozinskij: First published by Efim Etkind. Pasternak refers to K.I.Čukovskij's article, "Distorted Shakspeare", Published in Pravda (November 25, 1939). In his book The Lofty Art, Moscow (1941), Čukovskij turned on both Radlova and Lozinskij. 


\section{M.L. LOZINSKIJ, LETTER TO PASTERNAK}

- "Min's translation...": M. Lozinskij refers to the Russian translation of Divine Comedy written by D.B. Min (1818-1885).

" "GIHL": Gosudarstvennoe Izdatelstvo Hudozhestvennoj Literatury (State Fiction Publishers).

- "MHAT": Moscow Art Theatre. Hamlet in B. Pasternak's translation was not put on.

- "The conference on Shakespeare": conference devoted to translations of Shakespeare, in particular, to Radlova's translation, was held in Febuary 1940.

\section{MIKHAIL GASPAROV, EXPERIMENTS FOR MYSELF}

Being a philologist and a classicist by profession I confine myself almost exclusively to translating Latin and Greek poetry and prose. Traditionally, only philologists have undertaken such translations, for the omnivorous average translator is generally put off by the relatively low price of such work. The so-called great poets of this century also keep away from classical literature. However, there are a few exceptions: for the translation of a book of selected verse by Horace, the fanatical Jakov Golosovker engaged not only the poet Ilya Selvinskij but also Boris Pasternak. The resulting translations were good and not in the least out of style with the standard set by the philologists. Curiously enough, in translating Arabic and Persian classical poetry - a sphere no less specific the situation is different: there most poetic translations are made (or at least were made) by poets who used interlinear translations and who had no philological education. This approach probably had certain advantages, but the requirements of accuracy are much lower for translations of classical Oriental poetry than for those of classical Latin and Greek poetry. Maybe, this means that even the classical Orient was of more vital importance for Soviet culture than literature of classical antiquity. Orientalists have often told me this. Another person who expressed the same opinion was S.V. Šrvinskij who masterfully translated from classical originals as well as from Oriental interlinear renderings.

Besides the rule of accuracy, a translator who is also a philologist knows, or should know better than anyone, another rule which contradicts the first. This second rule was formulated at the beginning of this century by the king of classical philology, $\mathrm{U}$. Wilamowitz-Moellendorff: "Translations from language into language do not exist as such - there are only translations from style into style." The person who thinks that he is translating regardless of style, honestly and accurately, is still translating into a style, but it is usually bad style, hackneyed and stilted. As proof Wilamowitz offers a brillant experiment which only he could have undertaken. How can you translate "Uberallen Gipfelen ist Ruh" by Goethe into Ancient Greek? It is a dead language - no matter how hard you try to develop a new style in it, it will still remain dead. This means that you should choose a style from the existing stock. It turned out that there are two suitable styles: archaic lyric verse (fortunately, Ibicus has a passage about the night) and Alexandrian epigram. So Wilamovitz translates the eight lines by Goethe first using one Greek style, then the other. The translations come out very convincing and expressive, but you could not call them accurate without stretching a point.

Unlike Ancient Greek, Russian is not a dead language, but it turns out that this does not make stylistic work any easier. Creating a new Russian style to match the style of a foreign language, in cases when the Russian literary tradition does not have the relevant experience, turns out to be a tremendously difficult task. As for translating classical material I know of only two successes in finding an adequate style: N. Gnedič's translation of the Iliade and M. Kuzmin's translation of the Golden Ass. And the surprising thing is that Gnedix's feat in doing more than he knew he was doing - creating a new artificial poetic 
language - has remained absolutely without successors. No one has mastered this language even to the extent of translating the Odyssey without shocking the Russian readership by the wide stylistic gap between the two classical Russian translations - of Homer's Iliade (translated by N. Gnedič) and the Odyssey (translated by Zhukovskij).

Style means, roughly speaking, finding the right degree of archaisation and vulgarisation of the text. Have I got sufficient knowledge for that? I do not think I have. I do not know the modern jargon of the streets - fortunately it is not absolutely essential for translating classical poets (maybe only for Catullus' obscene sneers?). I know that in Puškin's epoch, for instance, the word pokamest (instead of poka-while) or the word nado (instead of nuzkhno-need) were vulgarisms; ibo (instead of potomucto-because) was archaic; ezheli (instead of esli-if) and slovno (instead of budto-as if) were colloquialisms; that at that time people wrote vorotitsja instead of vernutsja (come back) and preferred the conjunction nezheli to the conjunction cem (than). Unfortunately, even such things are not generally known now. I can understand the horror of my friend Sergei Averintsev when his wonderful translations of Byzantine authors are sincerely praised for the masterful way in which they achieve 15 th-century style, while in actual fact what they achieve is 17th-century style, but I myself could not achieve an impeccable translation of a classical author into the old Russian style. When I started translating Ariosto I wanted to put him into the language of 18th-century Russian novels, for Orlando Furioso and our Bova Korolevic (old broadside book Bova the Prince) are from the same genre of tales of chivalry and were both written at a point when the genre was about spent. I could not do that: I had to introduce artificial elements, unreal for the language of the period, but stylistically effective. Similarly, the peasants in Plody Provenscenija (The fruits of Enlightenment) by Leo Tolstoy speak using a terrible mixture of utterly incompatible dialects and this proves to be much more expressive than linguistic verisimilitude. Which is a pity.

Archaisation should be mesured - but how? We usually translate classical authors into 19th-century Russian or, at best, into Puškin's Russian. But more than 20 years ago my colleagues and I had to compile and translate an anthology Monuments of Medieval Latin Literature. It was necessary to convey the feeling of a different epoch, not classical, but vulgar and clerical Latin. This meant that we had to be guided by a more primitive style, that is, if we consider the Russian arsenal of styles - an older style. It could be, say, 17th-century style, whose syntax is simplified and whose vocabulary is a gaudy mixture of formal, bureaucratic, colloquial and church Slavonic words. Thus we tried to style our translations - each one of us to the best of his abilities. But the medieval writers were different: some of them wrote in a slap-dash style, others read the classical authors whose works they could come by and imitated them, sometimes quite well. We also tried to show this difference in the translation and for the medieval Ciceronians, like John of Salisbury, we again choose 19th-century Russian. Here lies the paradox: those who are more classical themselves and those who imitate the classical Latin authors, we translate using a more modern, Puškinian and post-Puškinian language, and to translate the later medieval Latin writers we use more archaic Russian. I should think many a translator has noticed this paradox if he has earnestly tried to preserve the feeling of stylistic perspective in translation.

A. Toynbee once did a brilliant experiment: he translated a collection of extracts from the Greek historians, modernising their style to the extreme - introducing footnotes, brackets and that indiscriminate Lexical Volapük which he uses so masterfully in his own Study of History, where the Greek agora becomes a piazza, and Cato's suicide turns into hara-kiri. A. Waley translated Japanese drama, but he purged it of all the names that were difficult to pronounce and all the national-specific elements that a foreigner 
could find hard to understand. For a preliminary acquaintance with an alien culture this is a necessary stage. We have very few translations like these which do not bring the reader closer to the original, but on the contrary, bring the original closer to the reader. I would like to make two versions of the same classical piece; one for the experienced reader and the other for beginners. I wonder how different the two would be.

There are two translations which I have found most difficult from the point of view of precision. They are very different.

The first is Poetics by Aristotle. Here precision means literal translation, because every word of the original has been so variously interpreted and so much built upon that you cannot change anything in the text. At the same time the style of Poetics is the style of private notes in which, for the sake of brevity, everything is omitted which it is possible or even impossible to omit. One could translate it word for word, but then one would need a whole story by way of commentary, so that the reader could understand it. I tried to find a compromise. I translated word for word but for the sake of at least syntactic clarity, I introduced additional words in angular brackets: omitting them the reader could perceive Aristotle's style of brief notes; reading them he could understand the content. As Greek syntax is very unlike Russian, it took a great deal of effort to make this double reading possible. The other translation was Ars Poetica by Horace. Once I translated it into prose for a scientific paper; the second time, for a collection of Horace's verse I made a poetic translation. It would be interesting to make a formal comparison of these two translations (considering "the precision quotient" and "the deviation quotient"). Also difficult from the point of view of achieving precision, was the translation of The Lives and Opinions of the Eminent Philosophers by Diogenes Laertius: each one of the Greek philosophical terms had to be given one and only one corresponding equivalent in Russian, even if different philosophers understood it differently. There was no existing tradition for me to lean on; many terms I had to invent myself. The ambiguity of Greek words sometimes drove me to despair. How can you translate Logos? T.V. Vasil'jeva found a wonderful Russian analogue, as polysemantic as the original: tolk-but this word is rather informal in Russian and to match it one would have to change the whole terminology from top to bottom, which I did not dare to do.

Yet another translation that required great precision was the translation of Cento by Ausonius, a Roman 4th-century decadent. It is an epithalamium several hundred lines long composed wholly, like a mosaic, of Vergilian hemistiches. A wedding was celebrated at court; the Emperor wrote a song in honour of the newly-weds and suggested that Ausonius do the same. It was dangerous to write better than the Emperor and it was obviously very difficult to write worse. Ausonius found a way out, making up his song entirely of words taken from Vergil so that he could always say: "If the song is good, it is not my achievement, but Vergil's". The artistic effect of the poem clearly lies in the fact that the old hemistiches in a new context is perceived against the background of the old (Vergilian) context. Roman readers certainly had knowledge of the Vergilian context, which cannot be expected from Russian readers. This meant that to each one of Ausonius' hemistiches I had to add two or three lines from Vergil in whose context the hemistiches would sound the same but mean quite a different thing. Certainly, the best option would have been to take these lines from the old translations of Vergil. However it turned out that in most cases it was impossible: when poets translated the Aeneid as a whole, keeping one big episode at a time in mind, they often sacrificed (for the sake of expressiveness) just those little things in the hemistiches which I needed so badly. The better and the more natural the translation of the Aeneid was as a whole, the less it was suitable for my translation of Ausonius' Cento. Valery Bryusov set out to translate the Aeneid with literal precision so that anyone quoting a small extract of the translation 
could be sure it corresponded exactly to the original. However, he did not achieve his aim. For me, that was an illustration of how much the theoretical notion of "the lenght of context" (or, in other words, "the measure of precision") can mean in translation.

As for style, Aesop, the most primitive of the authors I have translated, proved to be the most difficult. It is not by chance that every national literature has a rich stock of short retellings of Aesop's fables but no noteworthy translations of Aesop. It is a peculiarity of the fable genre that it is indifferent to style and the stylist has hardly anything to hold on to here. What should I write, Pastuh pošel v les $i$ vdrug uvidel... (The shepherd went to the forest and suddenly saw...) or Pošel pastuh v les $i$ vdrug vidit... (lit.: went the shepherd to the forest and suddenly he sees?) In Russian the intonation is very different in these two cases, but which one is closer to the intonation of the original - I did not feel the intonations of the Greek language well enough to decide. So I had to take a roundabout way: I took a big Spanish monograph on the vocabulary of Aesopica and went through marking all Aesop's fables in pencil - Attics words in red, vulgarisms in blue, intermediate forms in other ways, a different way for each. Then the fables which had more red in them I translated using the more neutral patterns like "Pastuh pošel v les" (the shepherd went to the forest) and in those fables that had more blue I used more expressive and colloquial patterns like "Pošel pastuh v les..." (lit.: went the shepherd to the forest). For me it was very exiting: I do not know if it was any use to the reader.

The two translations that I treasure most of all are not even considered to be mine officially. They are two books by Herodotus ("translated by I. Martynov, revised by M. Gasparov") and seven lengthy passages from Thucydides ("translated by F. Miščenco and S. Zhebelev, revised by M. Gasparov"). We were preparing a collection called Greek Historians: Herodotus, Thucydides, Xenophon. Usually historical prose is translated like a document: all the attention is given to facts and none to style. The late S.A. Ošerov and I wanted to represent it as artistic prose and in order to do this - to show the difference between the style of the three generations and the individual styles of these three very original writers. S. Ošerov translated Anabasis by Xenophon anew, using modern language, wonderfully exact and pure. Thucydides was taken in the translation made in 1887 (revised in 1915), Herodotus - in the translation of 1826 with all the peculiarities of the then official scientific style. The historical and stylistic perspective could be seen quite clearly. However, it was impossible to leave the translations unrevised. Herodotus wrote using smooth phrases, but Martynov often translated him using short, clipped sentences; Martynov's syntax had to be altered without changing his vocabulary and without exeeding the syntactical means available in early 19th century Russian. Thucydides is the most laconic and powerful among the Greek prose-writers, but Miscenko and Zhebelev, having very skillfully preserved all the complexity of his meaning, made him about twice as wordy as he actually is. Thucydides' laconic style had to be restored without making the meaning less explicit. The job was very tough but I profited from it: it taught me a great deal.

Very few translators like to revise their predecessors (or contemporaries). Many of them say: "I prefer to translate on blank paper". I have done a lot of revising, it was a shame to waste what was good (even if it was not much) in the old translations. There was one curious case of historical nemesis. The poet Innokentij Annenskij, the translator of Euripides, died in 1909, without publishing the complete version of his translation. The publishers and the poet's relatives entrusted the manuscript to his friend Th. Zielinskij, the translator of Sophocles. Zielinskij published Annenskij's translations having edited them ruthlessly - he changed about 25 per cent of the lines in the text. When the relatives started to object, Zielinskij answered: "I did it in the interests of Euripides, the readers and Annenskij's good name; I did with his inheritance what I would like someone to do with mine after my death". This is exactly what was done with his inheri- 
tance 70 years later: his translation of Sophocles was being prepared for publication and it turned out that without a great deal of editing (in the interests of Sophocles, the readers and Zielinskij's good name) it was impossible. The editing was entrusted to V.N. Jarho and myself. We were more lenient with Zielinskij than he was with Annenskij and we did not change more than 10 per cent of the lines in the text; I do not know whether Zielinskij in the other world was pleased with the job we made of it.

I am glad to have often translated verse: this teaches you to keep your style compressed and to treasure every word and every syllable - even in prose. Prose always has a rhythm of its own, but few can perceive it; the rhythm of Cicero's oratory is often translated into the rhythm of business documents. I went from this extreme to another: when I translated one of Cicero's speeches, S.A. Ošerov, who edited the book, said disapprovingly: "You have made him speak in verse!" - and he carefully removed the excessive rhythm. There is a late classical comedy Querolus in which every phrase or part of a phrase starts off as prose and finishes as verse. For two different editions I published the same translation in different typographic forms - for the first one in verse lines and for the second as prose, and I would like to make a psycholinguistic study of how the two are perceived by the reader. Once in a monograph on versification, I needed a sample of free verse. with a translation. I took 10 lines from Whitman with the classic translation by Kornej Cukovskij. It was a good translation but for one thing: Cukovskij rendered the English "free" rhythm by Russian "free" rhythm, but the Russian words are one and a half times longer than the English ones, and as a result the rhythmical tension - which was the most important thing - was completely lost in translation. I started editing the quotation, compressing the words and phrases and the upshot of it was that I had to write my own name under the translation: I had made a new translation.

It is easier for the translator of classical poetry to be precise, than it is for the translator of Modern European poets; Greeks and Romans did not have rhyme. I only once had to do a long rhymed translation - but then the rhymes were numerous, each quatrain having one rhyme. It was some poetry by medieval goliards, and the translation was considered good, but the memory is still so fresh of the pangs of remorse I suffered when, for the sake of rhyme, I had to use phrases I would never have used in translating classical rhymeless verse, that I swore never to take up rhymed verse again.

Moreover, I wonder, if for the sake of preserving the form you have to sacrifice precision, maybe it makes more sense to translate in the way they now do in the West: using free verse, without rhyme or meter, but, thanks to that, with maximum precision in rendering the style and meaning. It is not our tradition to do it like that and even in the West there are people who do not favour this tendency ("it's neither verse nor prose, a translators' lingua franca," said one of the reviews). I have often thought that some interlinear translations given in prose in the footnotes are sometimes more expressive than the poetic translations themselves. Certainly, you cannot translate everything like this; there are poems in which the rhythm and the euphony are hardly less important than the meaning of the words, and here they have to be preserved. I could translate Verhaeren without rhymes, but not Verlaine, could translate Ariosto's octaves into free verse, but never Don Juan. I have translated much verse preserving "the meter of the original", I have transferred very complex meters ( $c f$. "the rhopalic verse!"), so I decided that I had the right to experiment.

I have made quite a number of translations of classical verse into free verse, employing various forms of free verse - from free proper to all kinds of modifications which in one way or another were closer to the syllabic or accented verse. While doing this I learnt a few things that might be interesting for the theory of versification, but that is besides the point here. First I made such translations for myself alone. When I showed some of 
them (rather warily) to some of the specialists (philologists and translators) whom I respect, the succession of reactions was the same: first - a bad shock, then: "but this is interesting!" Now some of those translations have been published and some are in print.

Looking back, I can say that it was not by chance that I chose the materials I used for the experiments. The first were La Fontaine and the other European authors of 17-18thcentury fables. I chose these for a large anthology of fables. Experience shows that any translation of a European fable using traditional Russian verse is perceived as a pitifully disfigured Krylov. I saw my task as preserving the individuality of the originals. I cannot my free verse came out well, but I am afraid a traditional translation would have been still worse. Then there was Pindar. Here it was possible to lean on the tradition of translating Pindar's verse into free verse which had been formed in the German Sturm und Drang school: I think, I succeded in this. After that came Milton's Lycidas: any philologist can see that Pindar was the model for Milton's funeral Threnos and I thought of trying the form of the model on the imitation. Next - The Holy Sonnets by Donne: the form of the sonnet is the most inconvenient for preserving imagery and intonations and I thought they were of major importance in Donne's poetry. Later on there was the huge Orlando Furioso by Ariosto, where the sedate euphony of the original prevented me from perceiving the tangled plot, the sedate disharmony of old, fragmentary verse translations proved to be even more of an obstacle; so I decided that a flexible and varying free verse (without rhyme or meter, but corresponding line for line and stanza for stanza!) could make the perception of the plot much sharper. Next there came Euripides. Innokentij Annenskij had endowed the Russian Euripides with a decadent flabbiness which was so very unlike the Greek poet. To overcome this I translated one of his dramas into a concise iambic pentameter with masculine rhymes just like English blank verse; after that I started on a second drama, but then I got the feeling that the iambus was making my language stale. To get rid of the cliches I made a second translation - this time in well ordered free verse. Now those two translations, proceeding from the same idea but going along different paths, are lying in my desk drawer. I would not like to speak now of other authors whom I have translated in passing (of which I like W.B. Yeats and Georg Heym most).

This experiment was followed by another, a more risky one. I thought: if we have abridged translations of novels (and I am sure that the abridged Russian versions of $D o n$ Quijote and Gargantua et Pantagruel were of more significance for Russian culture than the impeccable full-length translations) then, perhaps, there could also be abridged translations of lyric poetry. Every poem has passages whose impact is strongest and passages of secondary importance; and there are connective passages, though this hierarchy can be viewed differently by readers of different epochs. What if we try to show in translation a portrait of the original as seen through the eyes of our contemporaries, omitting or condensing what seems to us of little importance - in other words, what if we make of it an artistic concentrate? I well remembered the exercises done by Greek and Roman poets, who would often turn an epigram into an elegy or vice versa. In the anthology of fables there was a spruch by Hans Sachs, written with his usual verbosity; I shortened it a bit and felt no loss. Then I took F. Thompson's The Hounds of Heaven in which the paradoxical despair was weakened by Victorian longueurs; by purely stylistic means, without omitting a single link in the lyric plot, I managed to make it shorter, and to my mind more expressive to the modern reader. I reduced about a dozen or more poems by Verhaeren and Henri de Regnier to a still briefer form. Each one became two thirds or even half of what they had originally been. Verhaeren, deprived of his rhetorical embellishments, unexpectedly turned out to be very much like Georg Heym; who Regnier resembles in my translation I cannot really say. The type of verse has changed (the classical meter was substituted by free verse), the style has changed (instead of late 19th-century rhetoric, late 
20th-century conciseness), the imagery, ideas, and emotions have remained unchanged. Can we say that it is a translation of the original poem, or should we rather say that it is a new poem on the same subject? As a philologist, I would be greatly interested in getting an answer to this theoretical question. This is the first time that I speak publicly about these vivisectional experiments: I have never showed them to anyone up to now, to say nothing of offering them for publication.

There is another translators' tradition which has never been followed (or at least has always been frowned upon) in Russia. It is now even translating into free verse, but doing it in honest prose, as has been a long-standing custom in France. Now I am trying to translate Punica by Silius Italicus into prose and I see with surprise that the Roman baroque of its style looks even more effectively tense, than it would have done in the usual hexametric translation. However there is a long way to go till the end - maybe, nothing will come of it.

\section{AUTHOR'S NOTES}

$N$. Gnedic (1784-1833), mediocre in his original poem but a genius in his translation of the Iliad, and V. Zhukovskij (1783-1852) equally great in his own lyrical poetry and in his translations (including the Odyssey) - both were elder contemporaries of the great Puškin. Also working at the same period was the best Russian author of fables I. Krylov (1768-1844): his plots are mostly borrowed from La Fontaine, but his style is entirely Russian. I. Martynov in 1810-1820 translated in prose a whole library of Greek poets and prosaists; professor F. Mi-enko (1848-1906) made the best of the old translations of Greek historians; professor S. Zhebelev (1867-1941) in the next generation revised one of them and he did it very well. Professor F. Zielinskij (1859-1944), a wellknown philologist and classicist, was also a talented translator of Greek and Roman poets into Russian and into his native Polish. V. Bryusov (1873-1924) the initiator of symbolism in Russian literature translated very much from European languages; other outstanding symbolists were the sophisticated lyrical poet $I$. Annenskij (1856-1909), a philologist and classicist by speciality, and the skillful stylist $M$. Kuzmin (1872-1936). The unrecognised philosopher J. Golosovker (1890-1967) in 1948 published a volume of selected verse by Horace in translations made by himself and by other writers, including the wellknown Soviet poet I. Selvinskij (1899-1968) and B. Pasternak (1890-1960), who does not need to be introduced. S. Servinskij (1892-1991) whose first book of poems was published in 1924 and the second one - only as late as 1984, was a talented translator from Greek, Latin, Italian, French, Arabic, Armenian and many other languages. S.Ošerov (1931-1983) was, among other things, the author of the last and the best Russian translation of the Aeneid.

(Translated by Dr. Lyubov A. Prozorova) 